\title{
Loktanella pyoseonensis sp. nov., isolated from beach sand, and emended description of the genus Loktanella
}

\author{
Young Gun Moon, ${ }^{1}$ Seong Hae Seo, ${ }^{2}$ Soon Dong Lee ${ }^{2}$ \\ and Moon Soo Heo ${ }^{1}$ \\ ${ }^{1}$ Faculty of Marine Science, Cheju National University, Jeju 690-756, Republic of Korea \\ ${ }^{2}$ Department of Science Education, Cheju National University, Jeju 690-756, Republic of Korea
}

Correspondence
Soon Dong Lee
sdlee@cheju.ac.kr
Moon Soo Heo
msheo@cheju.ac.kr

The genus Loktanella, which was described by Van Trappen et al. (2004), originally contained three species, Loktanella salsilacus, L. fryxellensis and L. vestfoldensis. Subsequently, six other species, Loktanella hongkongensis (Lau et al., 2004), L. agnita and L. rosea (Ivanova et al., 2005), L. koreensis (Weon et al., 2006), L. maricola (Yoon et al., 2007) and L. atrilutea (Hosoya \& Yokota, 2007), have been described. Members of the genus Loktanella have been isolated from microbial mats in Antarctic lakes and marine environments such as marine biofilms, sediment, sea sand and seawater. In this paper, a novel pink-coloured, obligately halophilic bacterium isolated from beach sand was studied by using a polyphasic approach.

In the course of a study on the bacterial diversity of beach sand, strain JJM85 ${ }^{\mathrm{T}}$ was isolated from sand collected from Pyoseon Beach in Jeju, Republic of Korea, in July 2007. The sand samples $(1 \mathrm{~g})$ were suspended in $10 \mathrm{ml} 0.85 \%(\mathrm{w} / \mathrm{v})$ $\mathrm{NaCl}$. Aliquots $(100 \mu \mathrm{l})$ of serial dilutions were inoculated on marine agar 2216 (MA; Difco) and plates were incubated at $25{ }^{\circ} \mathrm{C}$ for 2 days. A pure culture was stored at $-80{ }^{\circ} \mathrm{C}$ in marine broth 2216 (MB; Difco) supplemented with a glycerol solution containing $20 \%$ (v/v) distilled

The GenBank/EMBL/DDBJ accession number for the $16 \mathrm{~S}$ rRNA gene sequence of strain $\mathrm{JJM}^{\mathrm{T}}{ }^{\top}$ is AM983542. water and $60 \%(\mathrm{v} / \mathrm{v})$ natural seawater. For phenotypic comparison, L. hongkongensis NRRL B-41039 $9^{\mathrm{T}}$ was grown on $\mathrm{MA}$ at $25^{\circ} \mathrm{C}$.

Unless otherwise specified, all phenotypic characteristics were examined using MA as the basal medium. Growth was tested on MA, nutrient agar (NA; Difco) and trypticase soy agar (TSA; Difco). Colony morphology and pigmentation were determined using a culture grown at $25{ }^{\circ} \mathrm{C}$ for 2 days. Cell morphology was observed under an Olympus light microscope equipped with phase-contrast optics (magnification $\times 400)$. Motility was assessed on a semi-solid agar tube containing marine broth (Difco) supplemented with $0.4 \%$ agar. Cells were inoculated by stabbing with a straight needle and the tube was incubated at $25{ }^{\circ} \mathrm{C}$ for 5 days. The presence of flagella was checked with a transmission electron microscope (JEM-1010; JEOL) using cells negatively stained with $2 \%$ phosphotungstic acid. Gram staining was performed using a Gram stain kit (bioMérieux) according to the manufacturer's instructions. Growth at $4-40{ }^{\circ} \mathrm{C}$ and $\mathrm{pH} 4.0-12.0$ was tested on MA and $\mathrm{MB}$. Sodium ion requirements for growth and tolerance of various $\mathrm{NaCl}$ concentrations ( $0-14 \%$ ) were determined on NA. Oxidase and catalase activities and degradation of agar, DNA and starch were determined according to Lányí (1985). Cellulose hydrolysis and flexirubin pigment 
production were determined as described by Bowman (2000). Hydrolysis of chitin and Tweens 20, 40 and 80 was determined according to Baumann \& Baumann (1981). Other physiological and biochemical properties were tested using API 20NE, API $50 \mathrm{CH}$ and API ZYM strips (bioMérieux) according to the manufacturer's instructions. For these tests, cells were suspended in a solution of $2 \%$ sea salts (Sigma). Results were recorded after $48 \mathrm{~h}$ incubation at $25{ }^{\circ} \mathrm{C}$ for API $20 \mathrm{NE}$ and API $50 \mathrm{CH}$ strips and after $4 \mathrm{~h}$ incubation at $37{ }^{\circ} \mathrm{C}$ for API ZYM strips.

Cells of strain $\mathrm{JJM} 85^{\mathrm{T}}$ were Gram-stain-negative, aerobic, motile rods (Fig. 1). Strain JJM85 $5^{\mathrm{T}}$, along with $L$. atrilutea (Hosoya \& Yokota, 2007), was motile by means of flagella, in contrast to the other species of the genus Loktanella (Van Trappen et al., 2004; Ivanova et al., 2005; Weon et al., 2006; Yoon et al., 2007). The results of the other cultural, biochemical and physiological tests are given in the species description and Table 1.

Genomic DNA was extracted and purified using a commercial genomic DNA extraction kit (Bioneer). Amplification of the 16S rRNA gene by PCR was performed using the universal bacterial primers $27 \mathrm{~F}\left(5^{\prime}\right.$ AGAGTTTGATCMTGGCTCAG-3') and 1492R (5'TACGGYTACCTTGTTACGACTT- $3^{\prime}$ ). The purified PCR product was sequenced directly using an ABI BigDye 3.1 sequencing kit (Applied Biosystems) and an automated DNA sequencer (ABI 3730XL; Applied Biosystems). 16S rRNA gene sequence fragments of strain $J J M 85^{\mathrm{T}}$ were compiled using SEQMAN software (DNASTAR) and the partial

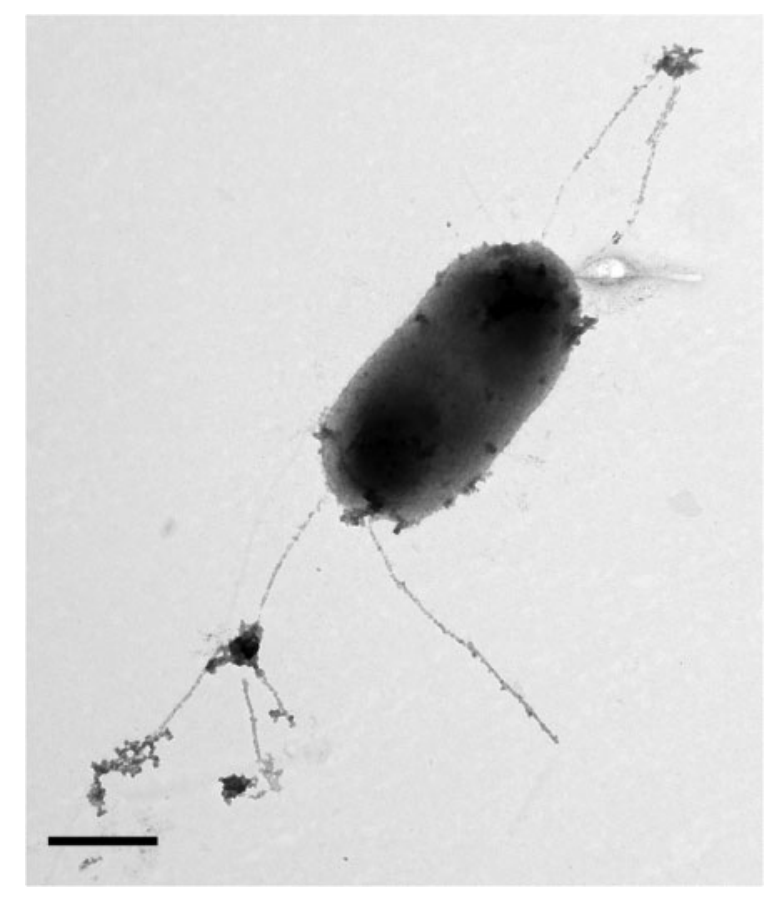

Fig. 1. Transmission electron micrograph of a cell of strain JJM85 ${ }^{\top}$ grown on MA at $25^{\circ} \mathrm{C}$ for 2 days. Bar, $0.5 \mu \mathrm{m}$.
16S rRNA gene sequence (1338 bp) was determined. The result of a preliminary BLAST search against GenBank showed that the isolate was related to members of the family Rhodobacteraceae. Multiple alignments of sequences were carried out using CLUSTAL_X (Thompson et al., 1997) and phylogenetic analyses were performed by using the neighbour-joining (Saitou \& Nei, 1987), maximumparsimony (Fitch, 1971) and maximum-likelihood (Felsenstein, 1981) methods. A phylogenetic tree was constructed using the neighbour-joining method and evolutionary distances were calculated with the model of Jukes \& Cantor (1969). A bootstrap analysis (Felsenstein, 1985) was performed with 1000 resampled datasets to estimate tree topology.

A neighbour-joining tree (Fig. 2) based on 16S rRNA gene sequences showed that strain $\mathrm{JJM} 85^{\mathrm{T}}$ belonged to the genus Loktanella and formed a robust cluster with the type strain of $L$. hongkongensis. This branching pattern was supported by a high bootstrap value (98\%) and was also found in trees obtained by the maximum-parsimony and maximum-likelihood treeing algorithms. 16S rRNA gene sequence similarities between strain $\mathrm{JJM} 85^{\mathrm{T}}$ and members of the genus Loktanella were as follows: L. hongkongensis NRRL B-41039 ${ }^{\mathrm{T}}, 96.0 \%$; L. maricola DSW-18 ${ }^{\mathrm{T}}, 94.1 \%$; $L$. rosea $\mathrm{Fg} 36^{\mathrm{T}}, 93.9 \%$; L. koreensis $\mathrm{GA} 2-\mathrm{M}^{\mathrm{T}}$, $93.9 \%$; L. agnita R10SW5 ${ }^{\mathrm{T}}$, $93.8 \%$; L. salsilacus LMG $21507^{\mathrm{T}}$, $93.7 \%$; L. atrilutea NCIMB $14280^{\mathrm{T}}, 93.6 \%$; L. fryxellensis $\mathrm{LMG}$ $22007^{\mathrm{T}}$, $93.4 \%$; and L. vestfoldensis LMG $22003^{\mathrm{T}}$, $93.1 \%$.

DNA-DNA hybridization experiments between strain $\mathrm{JJM} 85^{\mathrm{T}}$ and its phylogenetic neighbours were not carried out given the phenotypic distinctiveness of strain JJM85 ${ }^{\mathrm{T}}$ and $16 \mathrm{~S}$ rRNA gene sequence similarity values, which were lower than the recommended value of $97 \%$ used to delineate separate bacterial species (Stackebrandt \& Goebel, 1994).

Cellular fatty acids of strain $\mathrm{JJM} 85^{\mathrm{T}}$ and L. hongkongensis NRRL B- $41039^{\mathrm{T}}$ were analysed according to the instructions of the Sherlock Microbial Identification System (MIDI version 6). Fatty acid methyl esters were prepared from cells grown on MA for 3 days at $25^{\circ} \mathrm{C}$. The $\mathrm{G}+\mathrm{C}$ content of the DNA was determined by HPLC (Mesbah et al., 1989).

The cellular fatty acid profiles of strain $J \mathrm{JM} 85^{\mathrm{T}}$ and $L$. hongkongensis NRRL B- $41039^{\mathrm{T}}$ consisted of straight-chain saturated and unsaturated components with small amounts of hydroxy fatty acids; these profiles were similar to those of other members of the genus Loktanella (Van Trappen et al., 2004; Ivanova et al., 2005; Weon et al., 2006; Hosoya \& Yokota, 2007; Yoon et al., 2007). The dominant fatty acid of both strains was $\mathrm{C}_{18: 1} \omega 7 c$, but they differed from each other by the presence/absence of the minor components 11-methyl $\mathrm{C}_{18: 1} \omega 7 c$ and $\mathrm{C}_{16: 1} \omega 7 c$. The fatty acid profiles of strain $\mathrm{JJM}^{\mathrm{T}} 5^{\mathrm{T}}$ and L. hongkongensis NRRL B$41039^{\mathrm{T}}$ are given in Table 2. The DNA G $+\mathrm{C}$ content of strain JJM85 ${ }^{\mathrm{T}}$ was determined as $67.5 \mathrm{~mol} \%$, whereas that of L. hongkongensis NRRL B- $41039^{\mathrm{T}}$ determined in this 
Table 1. Differential characteristics of strain $\mathrm{JJM}^{\mathrm{T}} 5^{\mathrm{T}}$ and species of the genus Loktanella

Taxa: 1, strain JJM85 ${ }^{\mathrm{T}}$ (this study); 2, L. salsilacus (Van Trappen et al., 2004); 3, L. fryxellensis (Van Trappen et al., 2004); 4, L. vestfoldensis (Van Trappen et al., 2004); 5, L. hongkongensis (Lau et al., 2004); 6, L. agnita (Ivanova et al., 2005); 7, L. rosea (Ivanova et al., 2005); 8, L. koreensis (Weon et al., 2006); 9, L. maricola (Yoon et al., 2007); 10, L. atrilutea (Hosoya \& Yokota, 2007). +, Positive; -, negative; w, weak; v, variable reaction depending on strain; ND, no data available. All taxa are Gram-stain-negative, aerobic rods and grow at $10-30{ }^{\circ} \mathrm{C}$. They are positive for catalase and oxidase, but negative for hydrolysis of agar and starch, arginine dihydrolase, hydrogen sulfide and indole production.

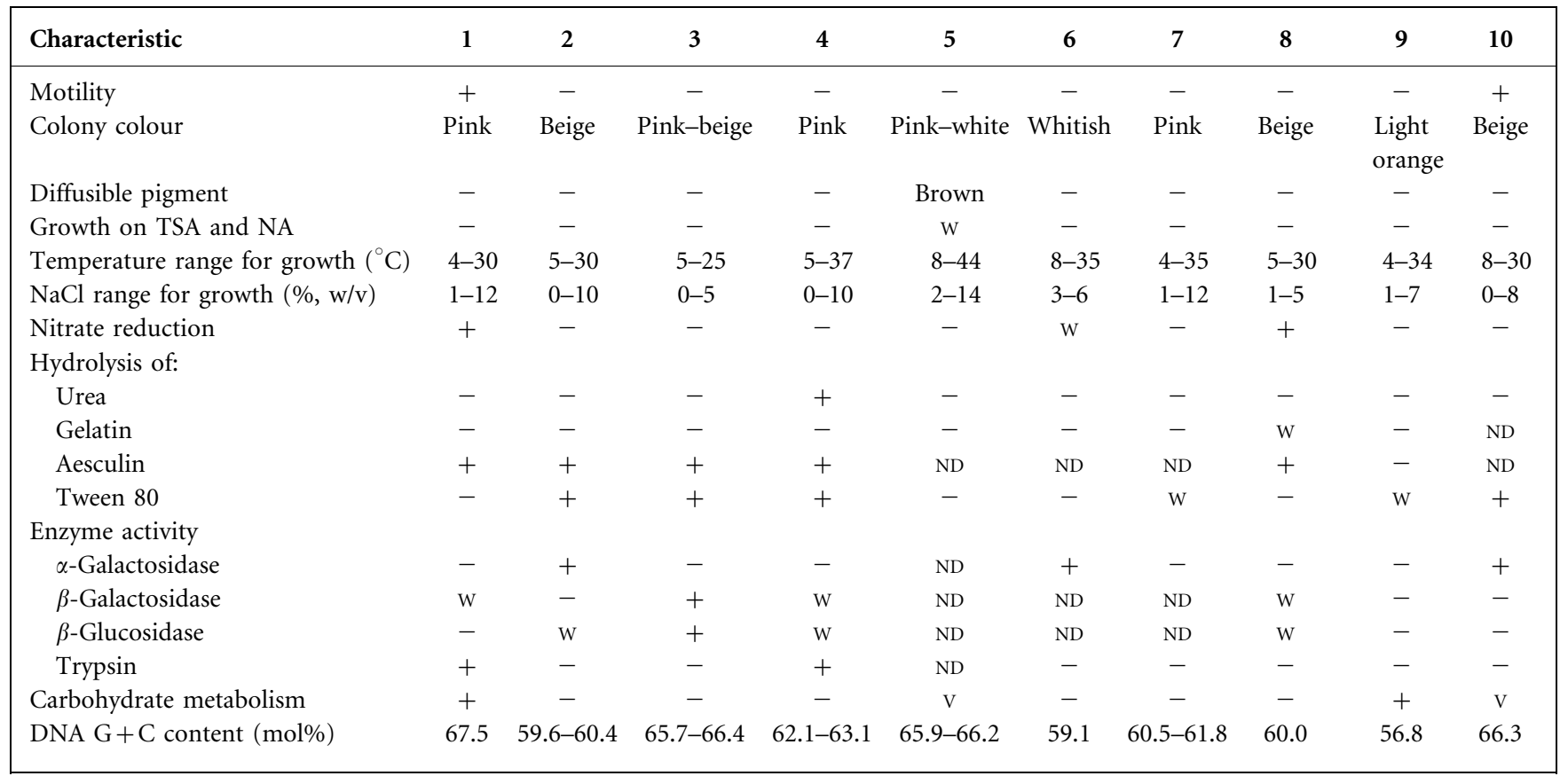

study was $65.7 \mathrm{~mol} \%$, which is within the range reported previously (Lau et al., 2004).

In our study, strain $\mathrm{JJM} 85^{\mathrm{T}}$ and L. hongkongensis NRRL B$41039^{\mathrm{T}}$ assimilated D-glucose, L-arabinose, D-mannitol and citrate as sole carbon sources, whereas strain $\mathrm{JJM} 85^{\mathrm{T}}$ showed additional utilization of $\mathrm{N}$-acetylglucosamine and maltose, in contrast to L. hongkongensis NRRL B-41039 ${ }^{\mathrm{T}}$. Both strains produced acid from D- and L-arabinose, Dfructose, lactose, D-mannitol, sucrose and L-xylose, but $L$. hongkongensis NRRL B-41039 $9^{\mathrm{T}}$ differed from strain JJM $85^{\mathrm{T}}$ in that it also produced acid from dulcitol, D-glucose, inositol, xylitol and D-xylose. Differential features of strain $J J M 85^{\mathrm{T}}$ and members of the genus Loktanella are given in Table 1.

On the basis of the phenotypic features and phylogenetic evidence presented here, strain $\mathrm{JJM} 85^{\mathrm{T}}$ represents a novel species of the genus Loktanella, for which the name Loktanella pyoseonensis sp. nov. is proposed. An emended description of the genus Loktanella is also presented.

\section{Emended description of the genus Loktanella Van Trappen et al. 2004}

Cells are Gram-stain-negative, strictly aerobic, moderately halotolerant, chemoheterotrophic, non-spore-forming and rod-shaped. Motility is variable among species; if observed, cells are motile by means of flagella. Cytochrome oxidase- and catalase-positive. Colony colours are variable (white, pink, whitish pink, beige or light orange) depending on the species. The optimal temperature for growth is $25^{\circ} \mathrm{C}$. The dominant fatty acid is $\mathrm{C}_{18: 1} \omega 7 c$. Q-10 is the major ubiquinone. The polar lipids are diphosphatidylglycerol, phosphatidylcholine and phosphatidylglycerol. DNA G + C contents are 59.1-67.5 mol\%. Phylogenetically, the genus belongs to the Rhodobacter group within the class Alphaproteobacteria. The type species is Loktanella salsilacus.

\section{Description of Loktanella pyoseonensis sp. nov.}

Loktanella pyoseonensis (pyo.se.o.nen'sis. N.L. fem. adj. pyoseonensis pertaining to Pyoseon Beach, Jeju, Republic of Korea, where the type strain was isolated).

Cells are Gram-stain-negative, aerobic and rod-shaped $(0.6-0.8 \times 1.3-3.0 \mu \mathrm{m})$. Motile by means of flagella. Colonies are circular, smooth, convex with an entire margin and pinkish in colour. Grows between 4 and $30{ }^{\circ} \mathrm{C}$ (optimum at $25^{\circ} \mathrm{C}$ ) and at $\mathrm{pH} 5.0-10.0$ (optimum at $\mathrm{pH} 7.0-8.0)$. Grows on NA supplemented with $1-12 \%(\mathrm{w} /$ v) $\mathrm{NaCl}$ (optimum at $2-5 \%$ ); growth does not occur on $\mathrm{NA}$ in the absence of $\mathrm{NaCl}$. Positive for catalase and oxidase activities and nitrate reduction, but negative for gelatin liquefaction, glucose fermentation, arginine dihydrolase and indole production (API 20NE). Does not grow 


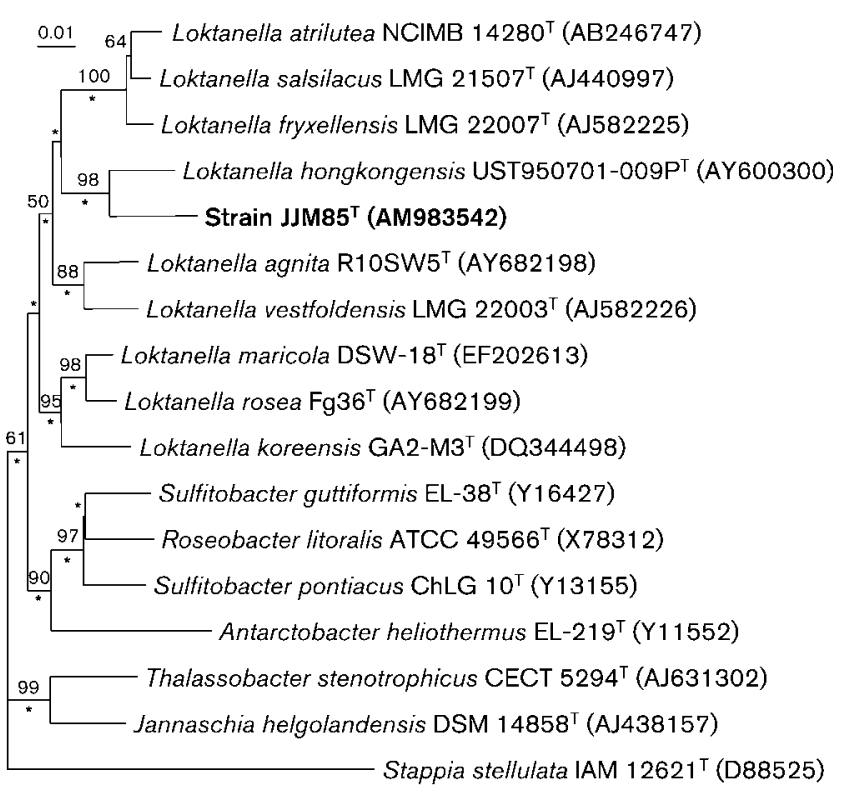

Fig. 2. Neighbour-joining tree based on 16S rRNA gene sequences showing the phylogenetic relationship between strain $\mathrm{JJM}^{\mathrm{T}} \mathrm{T}^{\top}$, Loktanella species and other related taxa. The tree was constructed based on an evolutionary distance matrix by using the neighbour-joining method (Saitou \& Nei, 1987) and the model of Jukes \& Cantor (1969). The sequence of Stappia stellulata IAM $12621^{\top}$ was used the outgroup. Bootstrap support values $(\geqslant 50 \%)$ are shown at branch points. Branches found in both maximum-parsimony (Fitch, 1971) and maximum-likelihood (Felsenstein, 1981) trees are indicated by asterisks. Bar, 0.01 substitutions per nucleotide position.

on TSA. Hydrolyses aesculin, but not agar, DNA, starch, Tween 80, tyrosine or urea. Assimilates $N$-acetylglucosamine, L-arabinose, citrate, D-glucose, maltose and D-

Table 2. Cellular fatty acid content of strain $J J M 85^{\top}$ and $L$. hongkongensis NRRL B-41039

Strains: 1, JJM85 ${ }^{\mathrm{T}}$; 2, L. hongkongensis NRRL B-41039 ${ }^{\mathrm{T}}$. Data were obtained in this study; both strains were grown on MA for 3 days at $25{ }^{\circ} \mathrm{C}$. Values are percentages of total fatty acids; values less than $1 \%$ of the total fatty acids were omitted. -, Not detected.

\begin{tabular}{|lcc|}
\hline Fatty acid & $\mathbf{1}$ & $\mathbf{2}$ \\
\hline Saturated & & \\
$\mathrm{C}_{16: 0}$ & 6.5 & 4.0 \\
$\mathrm{C}_{18: 0}$ & 1.3 & 3.0 \\
Unsaturated & & \\
$\mathrm{C}_{16: 1} \omega 7 c$ & 1.9 & - \\
$\mathrm{C}_{18: 1} \omega 7 c$ & 87.4 & 85.6 \\
$11-$ Methyl $\mathrm{C}_{18: 1} \omega 7 c$ & - & 1.1 \\
Hydroxy & & \\
$\mathrm{C}_{10: 0} 3-\mathrm{OH}$ & 1.4 & 1.8 \\
$\mathrm{C}_{12: 0} 3-\mathrm{OH}$ & 1.2 & 1.8 \\
\hline
\end{tabular}

mannitol as sole carbon sources. Acid is produced from D-arabinose, L-arabinose, D-fructose, lactose, D-mannitol, sucrose and L-xylose. Positive for alkaline phosphatase, esterase (C4) (weak), esterase lipase (C8) (weak), lipase (C14) (weak), leucine arylamidase, valine arylamidase (weak), cystine arylamidase (weak), trypsin, acid phosphatase (weak), $\alpha$-chymotrypsin (weak), naphthol-AS-BIphosphohydrolase (weak), $\beta$-galactosidase (weak) and $N$-acetyl- $\beta$-glucosaminidase (weak), but negative for $\alpha$-galactosidase, $\beta$-glucuronidase, $\alpha$-glucosidase, $\beta$-glucosidase, $\alpha$-mannosidase and $\alpha$-fucosidase (API ZYM). The main cellular fatty acid is $\mathrm{C}_{18: 1} \omega 7 c$. The DNA $\mathrm{G}+\mathrm{C}$ content of the type strain is $67.5 \mathrm{~mol} \%$.

The type strain is $\mathrm{JJM}^{\mathrm{T}} 5^{\mathrm{T}}$ (= KCTC $22372^{\mathrm{T}}=\mathrm{DSM}$ $21424^{\mathrm{T}}$ ), isolated from sea sand taken from Pyoseon Beach, Jeju, Republic of Korea.

\section{Acknowledgements}

This work was partially supported by the 21C Frontier Microbial Genomics and Application Center Program, Ministry of Science \& Technology, Republic of Korea. The authors are thankful for Dr A. P. Rooney for providing the type strain of L. hongkongensis.

\section{References}

Baumann, P. \& Baumann, L. (1981). The marine gram-negative eubacteria: genera Photobacterium, Beneckea, Alteromonas, Pseudomonas, and Alcaligenes. In The Prokaryotes, vol. 1, pp. 13021331. Edited by M. P. Starr, H. Stolp, H. G. Trüper, A. Balows \& H. Schlegel. Berlin: Springer.

Bowman, J. P. (2000). Description of Cellulophaga algicola sp. nov., isolated from the surfaces of Antarctic algae, and reclassification of Cytophaga uliginosa (ZoBell and Upham 1944) Reichenbach 1989 as Cellulophaga uliginosa comb. nov. Int J Syst Evol Microbiol 50, 18611868.

Felsenstein, J. (1981). Evolutionary trees from DNA sequences: a maximum likelihood approach. J Mol Evol 17, 368-376.

Felsenstein, J. (1985). Confidence limits on phylogenies: an approach using the bootstrap. Evolution 39, 783-791.

Fitch, W. M. (1971). Toward defining the course of evolution: minimum change for a specific tree topology. Syst Zool 20, 406416.

Hosoya, S. \& Yokota, A. (2007). Loktanella atrilutea sp. nov., isolated from seawater in Japan. Int J Syst Evol Microbiol 57, 1966-1969.

Ivanova, E. P., Zhukova, N. V., Lysenko, A. M., Gorshkova, N. M., Sergeev, A. F., Mikhailov, V. V. \& Bowman, J. P. (2005). Loktanella agnita sp. nov. and Loktanella rosea sp. nov., from the north-west Pacific Ocean. Int J Syst Evol Microbiol 55, 2203-2207.

Jukes, T. H. \& Cantor, C. R. (1969). Evolution of protein molecules. In Mammalian Protein Metabolism, vol. 3, pp. 21-132. Edited by H. N. Munro. New York: Academic Press.

Lányí, B. (1985). Classical and rapid identification methods for medically important bacteria. Methods Microbiol 18, 1-67.

Lau, S. C. K., Tsoi, M. M. Y., Li, X., Plakhotnikova, I., Wu, M., Wong, P.-K. \& Qian, P.-Y. (2004). Loktanella hongkongensis sp. nov., a novel member of the $\alpha$-Proteobacteria originating from marine biofilms in Hong Kong waters. Int J Syst Evol Microbiol 54, 22812284 . 
Mesbah, M., Premachandran, U. \& Whitman, W. B. (1989). Precise measurement of the $\mathrm{G}+\mathrm{C}$ content of deoxyribonucleic acid by highperformance liquid chromatography. Int J Syst Bacteriol 39, 159167.

Saitou, N. \& Nei, M. (1987). The neighbor-joining method: a new method for reconstructing phylogenetic trees. Mol Biol Evol 4, 406425.

Smibert, R. M. \& Krieg, N. R. (1994). Phenotypic characteristics. In Methods for General and Molecular Biology, pp. 607-654. Edited by P. Gerhardt, R.G. E. Murray, W. A. Wood \& N. R. Krieg. Washington: American Society for Microbiology.

Stackebrandt, E. \& Goebel, B. M. (1994). Taxonomic note: a place for DNA-DNA reassociation and $16 \mathrm{~S}$ rRNA sequence analysis in the present species definition in bacteriology. Int J Syst Bacteriol 44, 846849.
Thompson, J. D., Gibson, T. J., Plewniak, F., Jeanmougin, F. \& Higgins, D. G. (1997). The CLUSTAL_X windows interface: flexible strategies for multiple sequence alignment aided by quality analysis tools. Nucleic Acids Res 25, 4876-4882.

Van Trappen, S., Mergaert, J. \& Swings, J. (2004). Loktanella salsilacus gen. nov., sp. nov., Loktanella fryxellensis sp. nov. and Loktanella vestfoldensis sp. nov., new members of the Rhodobacter group, isolated from microbial mats in Antarctic lakes. Int J Syst Evol Microbiol 54, 1263-1269.

Weon, H.-Y., Kim, B.-Y., Yoo, S.-H., Kim, J.-S., Kwon, S.-W., Go, S.-J. \& Stackebrandt, E. (2006). Loktanella koreensis sp. nov., isolated from sea sand in Korea. Int J Syst Evol Microbiol 56, 2199-2202.

Yoon, J.-H., Kang, S.-J., Lee, S.-Y. \& Oh, T.-K. (2007). Loktanella maricola sp. nov., isolated from seawater of the East Sea in Korea. Int $J$ Syst Evol Microbiol 57, 1799-1802. 